\title{
ASSOCIATIONS BETWEEN SMOKING AND EMOTIONAL MENTAL DISORDERS AMONG ADOLESCENTS
}

\author{
Nova Dwi Astuti'1), Tri Yunis Miko Wahyono²) \\ 1) Masters Program of Hospital Management, Faculty of Public Health, Universitas Indonesia \\ 2) Department of Epidemiology, Faculty of Public Health, Universitas Indonesia
}

\begin{abstract}
Background: Adolescence is a crucial period for developing and maintaining social and emotional habit. Multiple factors determine the mental health of an adolescent. This study aimed to examine the associations between smoking and other factors with emotional mental disorders among adolescents. Subjects and Method: This was a cross sectional study. A sample of 9,819 junior and senior high schools was selected for this study. The dependent variable was mental emotional disorder. The independent variables were smoking status, age, gender, education, absence of close friend, relationship with parents, being bullied, and alcohol consumption. The data was obtained from Global School-based Student Health Survey (GSHS) in 2015. The data was analyzed by a multiple logistic regression.
\end{abstract}

Results: Mental emotional disorders increased with smoking status ( $\mathrm{OR}=1.60 ; 95 \% \mathrm{CI}=1.31$ to 1.97; $\mathrm{p}=<0.001)$, being bullied $(\mathrm{OR}=2.84 ; 95 \% \mathrm{CI}=2.45$ to $3.30 ; \mathrm{p}<0.001)$ and absence of close friendship ( $\mathrm{OR}=2.23 ; 95 \% \mathrm{CI}=1.59$ to $3.14 ; \mathrm{p}<0.001)$.

Conclusion: Mental emotional disorders are associated with smoking, being bullied, and absence of close friendship.

Keywords: smoking, bullied, mental emosional disorder, adolescent

\section{Correspondence:}

Nova Dwi Astuti. Faculty of Public Health, Universitas Indonesia, Depok, West Java, 16424. Email: aboutnovada@gmail.com. Mobile: 082292289882.

\section{BACKGROUND}

$\overline{\text { Adolescents are often considered a healthy }}$ population but in fact they are a group that is vulnerable to mental disorders. Currently, maintaining mental health has become a major focus in various countries because mental health is closely related to physical health. Mental health plays a major role in the ability of individuals to maintain better physical health. A person with a mental disorder will have a serious impact on his/her physical health including the development of various chronic diseases such as cancer, heart disease and diabetes (WHO, 2018).
Mental emotional disorders are health conditions characterized by changes in thinking, mood and/or behavior related to distress that can contribute to disability, illness, and death (Heshmat et al., 2016). Mental emotional disorders or psychological distress is a condition of someone who is undergoing psychological changes and this situation has a risk of becoming more serious if it is not treated and handled properly (Ayuningtyas, 2018).

World Health Organization (WHO) stated that $10-20 \%$ of adolescents in the world experience mental health disorders. Most adolescent health problems begin at the age 
of 14 with a condition that is underdiagnosed and not treated (WHO, 2018). In Indonesia, the prevalence of mental emotional disorders is 9.8\% (Basic Health Research, 2018). This prevalence has increased when compared to 2013 Basic Health Research by 6\%. Mental emotional disorders referred in Basic Health Research are disorders characterized by symptoms of depression and anxiety.

Globally, mental emotional disorders are caused by factors such as loneliness, anxiety, depression and emotional disorders that can affect adolescent conditions. Withdrawal from family, peers and social environment can lead to loneliness and alienation. The worst condition is that depression can increase the risk of suicide (WHO, 2018).

Adolescents with mental emotional disorder will be very easy to conduct health risk behavior such as smoking behavior. This is due to the limitations of adolescents to manage emotions supported by negative peer relationships. The involvement of adolescents in these health risk behaviors (smoking behavior) not only contributes negatively but will also greatly affect the mental and physical well-being of adolescents (WHO, 2018).

Smoking is a health problem that has become a habit and even lifestyle for the community. Smoking can increase the risk of morbidity of various diseases and mortality for users. WHO data in 2000-2017 showed the number of smokers, especially adolescents was still very large, which was more than 24 million children aged 13-15 years old (around 7\%). In the Southeast Asian region, the smoking prevalence rate for male aged $13-15$ years old is $8.8 \%$ (WHO, 2018).

The smoker population in Indonesia continues to increase, especially in adolescents. According to the results of Basic Health Research (2018), an increase in the prevalence of smoking among adolescents (10-18 years old) from 2013 to 2018 was $7.2 \%$ to $9.1 \%$. Based on the Global Youth Tobacco Survey (GYTS), Indonesia is declared as the country with the highest number of smokers in the world. Most adolescents start smoking at the age of 13 years old with a percentage of $31 \%$ in women adolescents and $21 \%$ in men adolescents (SDKI, 2018).

In smokers, the prevalence of nicotine dependence is higher in individuals with anxiety disorders. In the United States, the prevalence of heavy smoking ( 25 cigarettes/day) in the group without mental disorders was $10.3 \%$ and the prevalence of smoking with mental disorders/psychological distress was 28.8\%. A survey conducted in the United Kingdom states that $33 \%$ of groups with emotional anxiety disorders are smokers (RCP, 2013).

Some factors that influence the occurrence of mental emotional disorders are age, gender, education, relationships with friends, relationships with parents, harassment (bullied) and alcohol consumption. Best friends or close friends are associated with the emergence of symptoms of emotional mental disorders because friendship provides a more intimate relationship and is more influential on adolescent psychological development and mental health, better coping with stress thereby reducing emotional stress (Klima and Repetti, 2008).

Family factors play an important role in adolescent mental health because families with good communication between parents (especially mothers) with children about daily experiences will reduce stresssors faced by children (Nora and Thistle, 2011). Another factor is bullying and alcohol consumption in adolescents associated with mental health problems in adolescents (Tembo et al., 2017).

Based on this background, the authors were interested in knowing the relationship of emotional emotional disorders with adolescent smoking behavior in junior and senior high school students in Indonesia by 
using secondary data analysis from the Global School-based Student Health Survey (GSHS). GSHS is the result of a national school-based health survey in Indonesia which is a collaboration between WHO, the US Center for Disease Control (CDC) and the Ministry of Health Research and Development Agency in 2015. GSHS data used in this study were data related to adolescent risk behaviors consisting of behaviors smoking and emotional mental disorders in adolescents.

\section{SUBJECTS AND METHOD}

This study used a cross sectional design and was a secondary data analysis of GSHS 2015. The population consists of all junior and senior high school students registered with the Ministry of National Education were 75 schools in 26 provinces and 68 districts/cities in Indonesia. The sample in this study were junior and senior high school students who filled out the questionnaire completely, who were 9.819 students.

The dependent variable was an emotional mental disorder that has symptoms of loneliness and anxiety or excessive worry. The independent variable was the student's smoking behavior that was if he/she has smoked or in the past 30 days, he/she has smoked at least one day or if he/she can mention the age of first smoking. The characteristics examined in accordance with GSHS data were age, gender, education (junior and senior high school students), having close friends, relationships or closeness of parents with adolescents, being bullied, and using alcoholic beverages (minimum of one day consuming alcoholic drinks in the last 30 days when the study was conducted).
Friendship relationships between adolescents can be seen through the variable of friends, whether having friends (close friends at least one person) or not. Variable of relationship between adolescents with parents showed the closeness of adolescents with parents through frequent parents communicating openly and understanding adolescents' problems or concerns. Adolescents who experienced bullied such as physical abuse (beating, kicking, beating or being locked in a room) or racial, religious, sexual harassment or other forms of harassment.

The data source was derived from the results of the 2015 GSHS survey. Data analysis was carried out using univariate, bivariate and multivariate analyzes using a statistical data processing program (SPS version 20).

\section{RESULTS}

Analysis was performed on the data that was completely filled after going through a data cleaning process of 9,819 samples. Based on Table 1, adolescents who experience mental emotional disorders were 8.8\%. Middle adolescent adolescents who were in high school experienced more emotional mental disorders (10.4\%) than the early adolescent group (junior high school students). Based on gender, woman adolescent experienced more emotional mental disorders by $9.4 \%$. Table 2 showed that the characteristics of adolescents were mostly the group of early adolescents (aged 12-14 years old) who were in junior high school by 6.215 respondents (63.3\%). While the middle adolescent group (aged 1517 years old) who were in high school were 3,604 respondents (36.7\%). Characteristics of female adolescents were slightly more than males by 5,474 ( $55 \cdot 7 \%)$. 
Table 1. Emotional mental disorders in adolescents (middle school-high school students) in

\begin{tabular}{lccc}
2015 & & & \\
\hline \multicolumn{1}{c}{$\begin{array}{c}\text { Symptoms of Emotional Mental } \\
\text { Disorders }\end{array}$} & Category & N & \% \\
\hline Lonely & & & 1.4 \\
& Yes & 136 & 98.6 \\
Anxious/excessive worry & No & 9,683 & 7.4 \\
& Yes & 729 & 92.6 \\
Having Emotional Mental Disorders & No & 9,090 & 8.8 \\
& Yes & 865 & 91.2 \\
\hline
\end{tabular}

Table 2. Distribution Characteristics of Adolescents

\begin{tabular}{|c|c|c|c|c|c|c|c|c|c|}
\hline \multirow[t]{3}{*}{ Variables } & \multicolumn{6}{|c|}{ Emotional Mental Disorders } & \multirow{3}{*}{$\mathbf{p}$} & \multirow{3}{*}{$\mathbf{O R}$} & \multirow{3}{*}{ CI $95 \%$} \\
\hline & \multicolumn{2}{|c|}{ Yes } & \multicolumn{2}{|c|}{ No } & \multicolumn{2}{|c|}{ Total } & & & \\
\hline & $\mathbf{n}$ & $\%$ & $\mathbf{n}$ & $\%$ & $\mathbf{n}$ & $\%$ & & & \\
\hline \multicolumn{10}{|l|}{ Age } \\
\hline $12-14$ years old & 490 & 7.9 & 5,725 & 92.1 & 6,215 & 100 & 0.001 & 0.74 & $0.64-0.85$ \\
\hline 15 - 17 years old & 375 & 10.4 & 3,229 & 89.6 & 3,604 & 100 & & & \\
\hline \multicolumn{10}{|l|}{ Gender } \\
\hline Male & 353 & 8.1 & 3,992 & 91.9 & 4,345 & 100 & 0.033 & 0.86 & $0.74-0.99$ \\
\hline Female & 512 & 9.4 & 4,962 & 90.6 & 5,474 & 100 & & & \\
\hline \multicolumn{10}{|l|}{ Education } \\
\hline JHS (grade 7,8,9) & 587 & 8.4 & 6,422 & 91.6 & 7,009 & 100 & 0.017 & 0.83 & $0.72-0.97$ \\
\hline SHS (grade 10,11,12) & 278 & 9.9 & 2,532 & 90.1 & 2,810 & 100 & & & \\
\hline \multicolumn{10}{|l|}{ Friendship } \\
\hline $\begin{array}{l}\text { Do not have } \\
\text { bestfriends }\end{array}$ & 45 & 18.2 & 202 & 81.8 & 247 & 100 & 0.001 & 2.38 & $1.71-3 \cdot 31$ \\
\hline Have bestfriends & 820 & 8.6 & 8,752 & 91.4 & 9,572 & 100 & & & \\
\hline \multicolumn{10}{|l|}{$\begin{array}{l}\text { Relationship with } \\
\text { parents }\end{array}$} \\
\hline Not close & 599 & 9.4 & 5,795 & 90.6 & 6,394 & 100 & 0.008 & 1.23 & $1.06-1.43$ \\
\hline Close & 266 & 7.8 & 3,159 & 92.2 & 3,425 & 100 & & & \\
\hline \multicolumn{10}{|l|}{ Bullied } \\
\hline Yes & 337 & 17.2 & 1,624 & 82.8 & 1,961 & 100 & 0.001 & 2.88 & $2.49-3 \cdot 34$ \\
\hline No & 528 & 6.7 & 7,330 & 93.3 & 7,858 & 100 & & & \\
\hline \multicolumn{10}{|l|}{ Alcohol } \\
\hline \multicolumn{10}{|l|}{ Consumption } \\
\hline Yes & 66 & 18.4 & 292 & 81.6 & 358 & 100 & 0.001 & 2.45 & $1.86-3.23$ \\
\hline No & 799 & 8.4 & 8,662 & 91.6 & 9,461 & 100 & & & \\
\hline \multicolumn{10}{|l|}{ Smoking } \\
\hline Yes & 120 & 12.8 & 817 & 87.2 & 937 & 100 & 0.001 & 1.60 & $1.31-1.97$ \\
\hline No & 745 & 8.4 & 8,137 & 91.6 & 8,882 & 100 & & & \\
\hline
\end{tabular}

The results of the bivariate analysis (Table 2) showed that variables that fulfill the multivariate model criteria $(\mathrm{p}<0.25)$ were the main independent variables (smoking) and all confounding variables (age, gender, education, friends, relationship with parents, harassment/bullied, and alcohol consumption). Multivariate analysis was performed with complete modeling (Table 3) and excluded variables that had $\mathrm{p}>0.05$ 
which was education variables $(\mathrm{p}=0.875$; 95\% $\mathrm{CI}=0.814$ to 1.274 ). Interaction test results showed that there were no interacting variables. Confounding test was done by looking at the OR changes starting from the confounding candidate variable with the largest $\mathrm{p}$ value. The confounding candidate variable was considered as a confounding variable if the candidate variable was excluded and there was a change in the value of OR (changes $>10 \%$ ) the main independent variable before removing the candidate variable and after issuing the confounding candidate variable.

Table 3. Multivariate Analysis of Initial Modeling

\begin{tabular}{lcccc}
\hline \multicolumn{1}{c}{ Variables } & B & Nilai p & OR & 95 \% CI \\
\hline Smoking & 0.347 & 0.006 & 1.415 & $1.106-1.810$ \\
Age & -0.323 & 0.003 & 0.724 & $0.587-0.894$ \\
Gender & -0.389 & 0.0005 & 0.677 & $0.578-0.794$ \\
Education & 0.018 & 0.875 & 1.018 & $0.814-1.274$ \\
Friendship & 0.806 & 0.0005 & 2.238 & $1.592-3.147$ \\
Relationship with & 0.185 & 0.018 & 1.203 & $1.032-1.402$ \\
parents & & & & \\
Bullied & 1.045 & 0.0005 & 2.843 & $2.446-3.305$ \\
Alcohol & 0.551 & 0.001 & 1.735 & $1.272-2.368$ \\
Constants & -1.980 & 0.0005 & 0.138 & \\
\hline
\end{tabular}

The final model of multivariate analysis (Table 4) showed that the smoking variable has a value of $\mathrm{p}<0.05$ so that statistically, there was a significant relationship between the relationship of smoking behavior with the occurrence of mental emotional disorders and obtained 4 confounding variables, namely gender, relationship with parents bullied and alcohol consumption. An OR value of 1.46 ( 1,106 to 1,810 at $95 \% \mathrm{CI})$ mean that smoking behavior in adolescents has a 1.46 times more risk of developing mental emotional disorders than non-smokers.

Table 4. Multivariate Analysis of Final Modeling

\begin{tabular}{lcccc}
\hline \multicolumn{1}{c}{ Variables } & B & Nilai p & OR & 95 \% CI \\
\hline Smoking & 0.378 & 0.003 & 1.460 & $1.142-1.866$ \\
Gender & -0.378 & 0.0005 & 0.685 & $0.585-0.892$ \\
Relationship with & 0.190 & 0.015 & 1.210 & $1.038-1.410$ \\
parents & & & & \\
Bullied & 1.035 & 0.0005 & 2.815 & $2.425-3.268$ \\
Alcohol & 0.593 & 0.0005 & 1.809 & $1.327-2.467$ \\
Constants & -0.973 & 0.003 & 0.378 & \\
\hline
\end{tabular}

The results of the analysis also found the value of attributable risk (AR) as a result of the difference in risk between the exposure group and the outcome group that was 31.5\%. This showed that by eliminating smoking habits in adolescents, the likelihood for emotional mental disorders would decrease by $31.5 \%$ while still paying attention to confounding factors.

\section{DISCUSSIONS}

In this study, of 9,819 respondents, it was found that middle adolescents experienced more emotional mental disorders (10.4\%) than early adolescents. Although mental dis- 
orders can occur at any age, adolescence is a stage of development that places adolescents vulnerable to the risk of mental disorders. Based on psychosocial changes, the early adolescent group was adolescents aged 12-14 years old and middle adolescent adolescents were adolescents aged 15-17 years old (Batubara, 2010).

This was in line with research by Mubasyiroh, Putri and Tjandrarini (2016) that the higher the age, the higher the risk for experiencing emotional mental disorders. Symptoms of mental emotional disorders increase from childhood to adolescence and signs of increased symptoms appear between the ages of 13-15 years old to reach their peak around the age of 17-18 years old (Darmayanti, 2010). The influence of hormonal changes, cognitive maturity and in accordance with the characteristics of middle aged adolescents who still have unstable emotions and often have feelings of sadness or moody, symptoms of mental emotional disorders will also easily occur in this age group. The process of puberty in adolescence that was not well prepared would affect the psychological and emotional development, and it can lead to anxiety in adolescents (Batubara, 2010).

Based on gender, female adolescent experienced more emotional mental disorders. Malhotra and Shah's study (2015) explained that mood disorders, anxiety, psychological distress, and depressive symptoms occur 2-3 times more often in women.

Emotional symptoms and behavior such as irritability, anxiety, migraine, sleep disturbance, sadness and reduced concentration appear closely related to the luteal phase of the menstrual cycle. This was also in line with the research of Born, Shea and Steiner (2003) which stated that female adolescent have a higher vulnerability to the incidence of depression. Mental emotional disorders in early adolescence can originate from genetic traits and the influence of fe- male hormonal processes, and gender socialization. In women, the conflict would trigger hormones so that stress, anxiety and fear appear as a response to the brain that has negative alert to conflict and stress (Nasrani and Purnawati, 2015).

The results of multivariate analysis showed that there was a significant relationship between smoking behavior and mental emotional disorders in adolescents after being controlled by gender variables, relationship with parents, bullied and alcohol consumption. This was in accordance with research by Minichino et al. (2013), that smoking was associated with emotional mental disorders. A smoker would be more at risk of experiencing mental health problems such as mood disorders, anxiety disorders and psychosis. The strong effect of nicotine from smoking would increase adolescents' depression levels.

A cohort study conducted by Boden, Fergusson and Horwood (2010) of 1000 samples in New Zealand stated that a more appropriate causal relationship was the nicotine dependence of smoking behavior causing an increased risk of depression in adolescents. A systematic review study by Fluharty (2017) found that more than a third of studies showed that smoking was linked to the occurrence of anxiety disorders and depression later in life through effects on circulating neurons that increase susceptibility to environmental stressors. Animal experiments show that prolonged nicotine exposure causes damage to the hypothalamus-pituitary-adrenal system resulting in cortisol hypersecretion and changes in the activity of the monoamine neurotransmitter system whose function was related to regulating stress reactions.

Adolescents who were experiencing various changes in themselves need to be supported by well-being and good mental health. When they did not have this condition, adolescents would feel dissatisfied with their 
lives, experience less affection and excitement and more often experience negative emotions such as anger or anxiety (Rini, 2015). When individuals can not overcome anxiety with effective action then came the response of the defense mechanism. Immature self defense mechanisms in adolescents will cause psychological development that was disrupted, making it more difficult for individuals to cope with problems, both small and large, in an effective way (Winarto, 2008).

Freud's theory (in Sanyata, 2015) regarding self defense mechanism was associated with adolescent smoking behavior which was a form of individual repression to eliminate frustration, inner conflict, and various other anxiety that exists in a person. Smoking as an effort to overcome the psychological stress experienced by adolescents. If smoking was ignored until adulthood, it can increase the risk of more severe mental disorders even though smoking behavior can be prevented early.

The limitations of this study was that this study only analyzed the variables available in the 2015 GSHS data, namely age, gender, education, friends, relationship with parents, bullied and the use of alcoholic drinks. Future studies can further develop other variables contained in GSHS that might also influence smoking behavior and the occurrence of symptoms of mental emotional disorders in adolescents.

This study provided information that smoking was a behavior that contributes to the high number of morbidity associated with mental emotional disorders in adolescents. Health risk behaviors such as smoking were behaviors that can be prevented early on through the role of healthy friendships, the role of parents and teachers and the school environment in promoting promotive and preventive programs. The results of the study also showed the need to increase educational efforts regarding the management of adolescent emotions, prevention and early development of adolescent smoking behavior to support the creation of optimal mental health early.

\section{REFERENCES}

Ayuningtyas D, Misnaniarti, Rayhani M (2018). Analisis situasi kesehatan mental pada masyarakat di Indonesia dan strategi penanggulangannya (An analysis of the mental health situation in communities in Indonesia and its prevention strategies). Jurnal Ilmu Kesehatan Masyarakat Maret, 9 (1). Palembang: UNSRI.

Batubara JRL (2010). Adolescent development (perkembangan remaja). Sari Pediatri, 12(1).

Boden JM, Fergusson DM, Horwood JM (2010). Cigarette smoking and depression: tests of causal linkages using a longitudinal birth cohort. The British Journal of Psychiatry 196(6): 440-446. https://www.cambridge.org-

/core/journals/the-british-journal-ofpsychiatry/article/cigarette-smokingand-depression-tests-of-causallinkages-using-a-longitudinal-birthcohort/Co54720CC4CAF37C4CD96CD oE050773B

Born L, Shea A, Steiner M (2003). The roots of depression in adolescent girls: is menarche the key? Current psychiatry reports, 4(6):449-460. doi: 10.1007/s11920-002-0073-y

Darmayanti N (2010). Meta analisis: gender dan depresi pada remaja (meta-analysis: gender and depression in adolescents). Jurnal Psikologi 35(2): 164180. Yogyakarta: UGM. https://media.neliti.com/media/publications/1 28727-ID-metaanalisis-gender-dandepresi-pada-rem.pdf 
Fluharty M, Taylor AE, Grabski M, Munafò MR (2017). The association of cigarette smoking with depression and anxiety: a systematic review. Nicotine \& Tobacco Research 19(1): 3-13. https://www.ncbi.nlm.nih.gov/pmc/articles/PMC5157 $710 /$

Heshmat R, Qorbani M, Ghoreshi B, Djalalinia $S$, Tabatabaie OR, Safiri $S$ et al. (2016). Association of Socioeconomic status with psychiatric problems and violent behaviours in a nationally representative sample of Iranian children and adolescents: The CASPIAN-IV Study. BMJ. 6(8): e011615. doi: 10.1136/bmjopen-2016-011615

Klima T, Repetti RL (2008). Children's peer relations and their psychological adjustment differences between close friendships and the larger peer group. APA Psyc Net, 54(2), 151-178. https://doi.org/10.1353/mpq.2008.0016

Magklara K, Bellos S, Niakas D, Stylianidis S, Kolaitis G, Mavreas V et al. (2015). Depression in late adolescence: A crosssectional study in senior high schools in Greece. BMC Psychiatry 2015 (15). https://bmcpsychiatry.biomedcentral.com/articles/10.1186/s12888-0150584-9.

Malhotra S, Shah R (2015). Women and mental health in India: An overview. Indian Journal of Psychiatry 57 (2): 205-211. https://www.researchgate.net/publication/281517733_Women_a nd_mental_health_in_India_An_over view

Minichino A, Bersani FS, Calò WK, Spagnoli $\mathrm{F}$, Francesconi M, Vicinanza $\mathrm{R}$ et al. (2013). Smoking behaviour and mental health disorders-mutual influences and implications for therapy. International Journal of Environtmental Resesarch and Public Health 10. https://pdfs.semanticscholar.org- /2877/bae72796b4bb16f84aeb7ob41f5 bb1056216.pdf

Mubasyiroh R, Putri IYS, Tjandrarini, DH (2016). Determinan gejala mental emosional pelajar SMP-SMA di Indonesia tahun 2015 (Determinant of Emotional Mental Symptoms of Middle-School High School Students in Indonesia in 2015). Buletin Penelitian Kesehatan, 45(2): 103-112. doi: 10.22435/bpk.v45i2.5820.103-112

Nasrani L, Purnawati S (2015). Perbedaan tingkat stres antara laki-laki dan perempuan pada peserta yoga di kota Denpasar (differences in stress levels between men and women of yoga participants in Denpasar City). E-Journal Medika Udayana 4(12). https://ojs.unud.ac.id/index.php/eum/article/vie $\mathrm{w} / 18109$

Nora AC, Widuri EL (2011). Komunikasi ibu dan anak dengan depresi pada remaja (mother and child communication with depression in adolescents). Humanitas, 8(1). Yogyakarta: Universitas Ahmad Dahlan. https://media.neliti.com/media/publications/24640-id-komunikasi-ibu-dan-anak-dengan-depresipada-remaja.pdf

Rini OK (2015). Hubungan antara regulasi emosi dengan kesejahteraan subjektif pada remaja (the relationship between emotion regulation and subjective welfare in adolescents). Naskah Publikasi. Surakarta: Universitas Muhammadiyah Surakarta.

Royal College of Physicians (2013). Smoking and mental health. London: RCP.

Sanyata S (2009). Mekanisme dan taktik bertahan: penolakan realita dalam konseling (defense mechanisms and tactics: rejection of reality in counseling). Paradigma No. 08 Tahun IV Juli 2009: 35-44. 
SDKI (2018). Survey Demografi dan kesehatan Indonesia 2017 buku remaja (Indonesian demographic and health survey 2017 teen book). Jakarta: BKKBN BPS Kemenkes.

Tembo C, Burns S, Kalembo F (2017). The association between levels of alcohol consumption and mental health problems and academic performance among young university students. Plos One Journal 12(6). https://journals.plos.org/plosone/article?id=10.1371/journal .pone.0178142

Weis R (2008). Introduction to abnormal child and adolescent psychology. United States of America: Sage Publications Inc.

Wibowo M (2017). Perspektif hambatan terhadap kemungkinan remaja berhenti merokok (Perceived barrier to adolescent's possibility to stop smoking). Unnes Journal of Public Health 6(2). Semarang: Unnes.

Winarto AT (2008). Studi kasus mekanisme pertahanan diri remaja ketika menghadapi masalah perceraian orang tua (case study of adolescent self defense mechanisms when facing parental divorce problems). Skripsi. Yogyakarta: Universitas Sanata Darma.

WHO (2018). Adolescent mental health. Retrieved from https://www.who.int/news-room/fact-sheets/detail/adolescent-mental-health

WHO (2018). WHO global report on trends in prevalence of tobacco smooking 2000-2025. Geneva: WHO. 